UDK 528.711.7

\title{
LAIKOTARPIO TINKAMUMO KARTOGRAFUOTI ŽEMĖS NAUDMENAS PAGAL PALYDOVINES DAUGIASPEKTRES NUOTRAUKAS ANALIZE்
}

\author{
Arūnas Bujauskas ${ }^{1}$, Eimuntas Paršeliūnas ${ }^{2}$ \\ Geodezijos ir kadastro katedra, Vilniaus Gedimino technikos universitetas, \\ Sauletekio al. 11, LT-10223 Vilnius-40, Lietuva, \\ el.paštas: ${ }^{1}$ bujauskas@vzi.lt, ${ }^{2}$ eimis@ap.vtu.lt
}

Iteikta 200512 21, priimta 20060320

\begin{abstract}
Santrauka. Straipsnyje analizuojama, kuriuo žemès paviršiaus distancinių tyrimų laikotarpiu tinkamiausia kartografuoti žemès naudmenas. Žemès naudmenoms kartografuoti taikomos LANDSAT 5 ir LANDSAT 7 palydovais gautos daugiaspektrès nuotraukos, o laikotarpiai parenkami pagal šių palydovų skridimo virš Lietuvos teritorijos grafikus. Dėl Lietuvos teritorijos klimatinių sąlygų sudètingumo daugiaspektrès nuotraukos dažnai gaunamos nepakankamai kokybiškos, o tai sumažina tikimybę turèti tinkamus duomenis analizei ir kartografavimui.
\end{abstract}

Prasminiai žodžiai: nuotoliniai tyrimai, žemès naudmenos, skenavimo laikotarpis, palydovas LANDSAT, daugiaspektrè nuotrauka.

\section{Ivadas}

Nuotolinių tyrimų metodais galima nustatyti ivairiu žemès paviršiaus objektu vietą ir savybes. Iš viso spindulių spektro geriausiai infraraudonuosius spindulius atspindi vegetuojantys augalai. Pagal infraraudonuju spindulių atsispindèjimo nuo gyvos augalo ląstelès savybes nesunkiai nustatomos žaliosios masès apimtys ir vieta. Tačiau nuo augalų lapų paviršiaus atsispindi ne visi šie spinduliai, didžioji spindulių dalis ląstelèje išsisklaido $\mathfrak{i}$ lapo sieneles. Dalis pro augalija prasiskverbusiu spindulių atsispindi nuo žemès paviršiaus, todèl spektrinis atspindys priklauso nuo augalu rǔšies, tankio ir būklès. Atliekant įvairius tyrimus buvo nustatyta, kad didelès itakos atspindžiui $(10 \%)$ turi augaluose esantis vandens kiekis. Pagal gautus laboratorinių tyrimu rezultatus galima nustatyti augalų atspindžio charakteristikas, suklasifikuoti augalus pagal atspindi; nustatomas tyrimų rezultatų tikslumas. Nuotoliniu tyrimu metodas taip pat tinka augalijos brandai stebèti, nes, bręstant augalams, keičiasi jų vegetacinè būklè. Todèl, atsižvelgdami $\mathfrak{i}$ augmenijos augimo skirtumus, galime iš anksto planuoti žemès naudmenu kartografavimo galimybes.

Gauti kokybiškas palydovines nuotraukas Lietuvos teritorijoje trukdo klimatinès sąlygos, o ypač debesuotumas ir rūkai. Atliekant meteorologinius stebėjimus nustatyta, kad giedrų dienų Lietuvos teritorijoje daugiausia būna gegužès - rugpjūčio mènesiais $[1,2]$. Šiuo laikotarpiu didžiausia tikimybė gauti tinkamas daugiaspektres nuotraukas analizei ir kartografavimui atlikti.

Siekiama parinkti tinkamiausią žemès paviršiaus skenavimo laikotarpi tiriant ir kartografuojant žemès naudmenas nuotoliniu metodu. Straipsnyje pateikiami tinkamiausi laikotarpiai augalinès dangos plotams nustatyti šiuo metodu, pagal palydovines daugiaspektres nuotraukas bei išanalizuotos galimybès taikyti dviem specializuotais palydovais - LANDSAT 5 ir LANDSAT 7 gaunamas nuotraukas žemès naudmenoms tirti ir kartografuoti Lietuvos teritorijoje.

\section{Augalinės dangos ypatumų analizė}

Lietuva yra klimatinèje zonoje, kur per metus vegetacinis laikotarpis keičia nevegetacini periodą. Augalinès dangos vegetacinis laikotarpis prasideda skirtingu metu ir baigiasi nevienodai. Anksčiausiai parsideda žieminių javu ir daugiamečiu žalienų vegetacija. Vèliau sužaliuoja lapuočiai medžiai ir vasarinès žemès ūkio kultūros.

Reikia pažymèti, kad kiekvienais metais augalų vegetacijos pradžia, pabaiga, vasarinių ir kitų žemès ūkio kultūrų sèja, brendimas ir derliaus nuemimas priklauso nuo tų metų meteorologinių sąlygų ir gali labai nukrypti nuo daugiamečiu vidurkių (1 pav.) [1,2].

Lietuvoje vegetacijos pradžia gali svyruoti iki 20 dienų. Augalų augimo ir vystymosi intensyvumas taip pat svyruoja, nes esant vèlesnei vegetacijos pradžiai augimo sąlygos būna palankesnès. Balandžio - gegužès mènesiais žieminiai rugiai, kviečiai ir kitos žiemojančios kultūros sukaupe didelius biomasès kiekius, o vasarinès ir šilumamègès kultūros - tik sẻjamos. Rugpjūtị ir rugsèji jau nupjaunami javai, tačiau dar auga linai, cukriniai runkeliai, atauga daugiamečių žolių atolai. Tik birželio ir liepos mėnesiais žemès ūkio kultūros auga visuose laukuose (išskyrus pūdymus). 


\begin{tabular}{|c|c|c|c|c|c|c|c|c|c|c|c|c|c|c|c|c|c|c|c|c|c|c|c|c|c|c|c|c|c|c|c|c|c|c|c|c|}
\hline Lapuočiaimedri & & & & & & & & & & & & & & & & & & & & & & & & & & & & & & & & & & & & \\
\hline \multicolumn{37}{|c|}{ Spyghiuočiaimedriai } \\
\hline \multicolumn{37}{|c|}{ Daugiamelès žoles } \\
\hline \multicolumn{37}{|l|}{ Žiemminiai javai } \\
\hline \multicolumn{37}{|l|}{ Miečiai } \\
\hline \multicolumn{37}{|c|}{ Nevegetacinis periodas } \\
\hline Buhes & & & 4 & & & & +1 & & & & & & & & & & & & & & & & & & & & & \multicolumn{7}{|c|}{ Nevegetacinis periodas } & & \\
\hline \multicolumn{37}{|l|}{ Limai } \\
\hline \multicolumn{37}{|c|}{ Cukminiai runleliai } \\
\hline \multicolumn{37}{|c|}{ Žieminiai rapsai } \\
\hline \multicolumn{37}{|l|}{ Aviřos } \\
\hline Dekada & $I$ & 2 & 3 & $I$ & 2 & 3 & $i$ & 2 & 3 & 1 & 2 & 3 & $I$ & 2 & 3 & $I$ & 2 & 3 & $I$ & 2 & 3 & $I$ & 2 & 3 & I & 2 & 3 & $I$ & 2 & 3 & $I$ & 2 & 3 & $I$ & 2 & 3 \\
\hline Minuo & & vosis & & & $2 \operatorname{san}$ & & & Evas. & & & $2 \mathrm{kgnc}$ & & & gǚs & & & izžela & & & Liepa & & & gRjiu & & & ugseji & & & Spalis & & & aploith & & & mod & \\
\hline
\end{tabular}

1 pav. Augalijos vegetacinis ir nevegetacinis periodai

Fig 1. Vegetation and non-vegetation periods of the plants

Vienas laukas nuo kito skiriasi augmenijos antžeminès dalies aukščiu, tankumu, mase. Jeigu vienu metu kukurūzų ir miežių lauke biomasès kiekis ploto vienete bus vienodas, tai šiuo laikotarpiu gauta daugiaspektrė nuotrauka šioms dviems kultūroms kartografuoti netiks. Šiai problemai spręsti būtina kito laikotarpio daugiaspektrè nuotrauka, kurioje skirtusi šiu žemès ūkio kultūrų biomasès kiekiai, taigi ir spektrinis atspindys. Paprasčiau ir patikimiau atskirti žemès ūkio naudmenu plotus turint kiekvienos kultūros tiriamame plote augalų antžeminès dalies augimo kreives per visą vegetacijos periodą. Augalu aukštis labai susijęs su biomasès kiekiu. Tačiau kiekvienos žemès ūkio kultūros ši priklausomybė kitokia. Duomenys, kuriais remiantis galima analizuoti augalų skirtumus, būtụ labai naudingi parenkant fotografavimo laiką daugiaspektrèms nuotraukoms gauti.

Tame pačiame lauke dèl nevienodų augimo sąlygu (išmirkimo, drègmès trūkumo, ligų ir t. t.) augmenija gali būti skirtingo aukščio, išsivystymo ir masès. Išvada - augalu biomasės nustatymo metodika yra atskiras ir sudètingas klausimas. 2 pav. pateikta žieminiu kviečiu aukščiai jų vegetacijos periodu [1].

Turedami visų augalinès dangos rūšių augimo dinamikos grafikus ir biomasès kreives galime nustatyti datą, kada mus dominantis žemès dangos objektas yra nepanašiausias i kitus analogiškus objektus. Šis laikas geriausiai tinka distanciniams tyrimams.

\section{Augmenijos spektrinio atspindžio ypatumai}

Infraraudonuju spinduliu atspindys nuo augmenijos priklauso ne nuo augalo pigmento, bet nuo augalo ląsteliu struktūros. Augalo lapu gyvosios ląstelès yra beveik skaidrios infraraudoniesiems spinduliams, ir tik nedidelis spinduliu kiekis atsispindi nuo lapu paviršiaus epidermio. Didesné spindulių dalis (apie $60 \%$ ) ląstelèse susigeria ir tik mažesne dalis atsispindi.

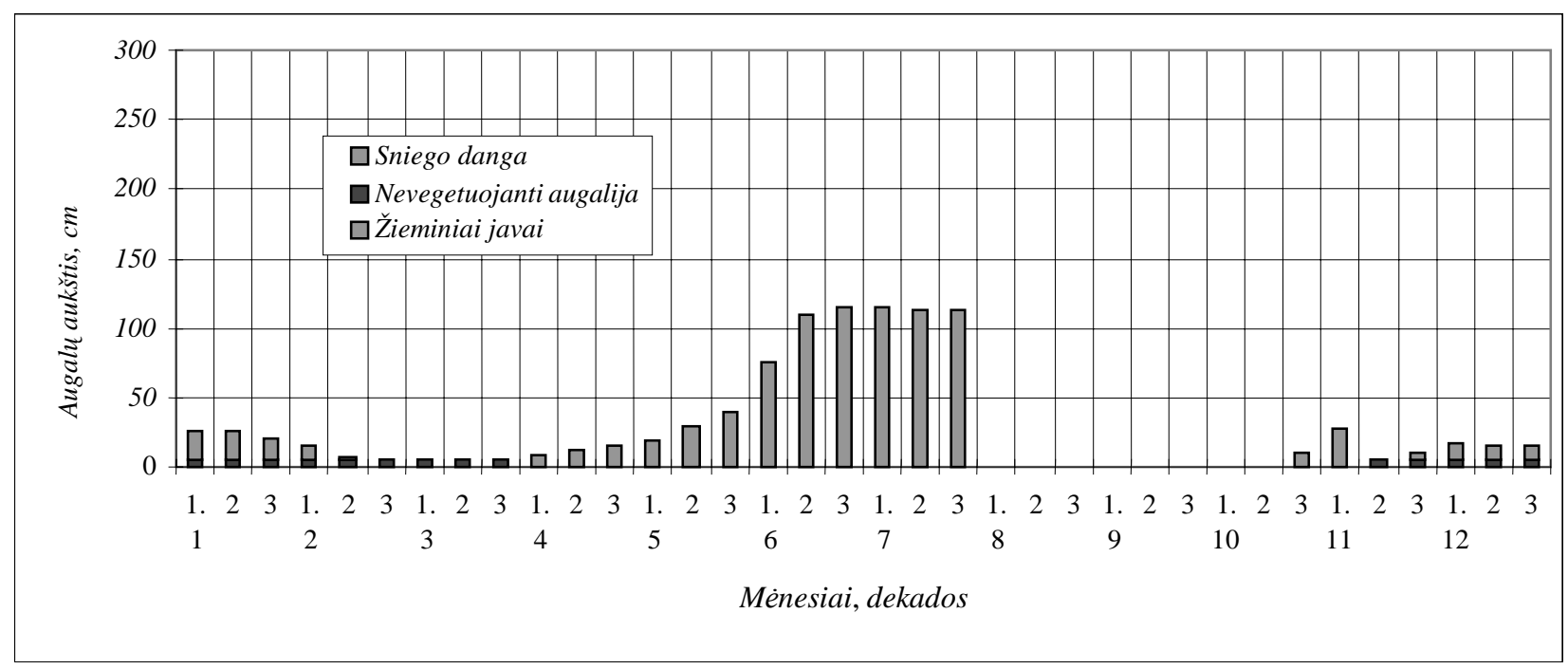

2 pav. Augalinès dangos aukštis žieminių kviečiu lauke

Fig 2. Vegetation height in a field of the winter wheat 
Palydovuose LANDSAT sumontuoti du skenavimo irenginiai: $M S S$ (daugiaspektris skeneris) ir $T M$ (skeneris teminiam kartografavimui). Palydove LANDSAT 7 geresnès kokybės skenavimo irenginys ETM+. Abieju LANDSAT palydovų skenavimo irenginiai registruoja žemès paviršiaus atspindi septyniose juostose.

$M S S$ irenginiu gauti duomenys naudojami žalios augmenijos atspindžiui ir chlorofilo sugerčiai registruoti. $T M$ ir ETM+ įrenginio duomenys naudojami ịvairiems žemès ištekliams tirti. Pirmoji atspindžio registravimo juosta tinka dirvožemiui ir augmenijai nuotraukose skirti. Pagal antrosios juostos duomenis galima nustatyti augalijos žalios spalvos atspindị. Trečioji juosta naudojama augmenijoje esančio chlorofilo sugerties lygiui nustatyti. Augalijai ir vandens paviršiui skirti skirta ketvirtoji juosta. Penktoji ir septintoji juostos skirtos dirvožemio ir augalijos drégmei tirti.

3 pav. parodyta tipinès augmenijos, dirvožemio ir vandens tipiškas atspindys bei $T M$ ir ETM+ skenavimo įrenginio atspindžio registravimo juostų išsidèstymas $[3,4]$.

Pastebime, kad stipriausiai atspindimi $0,7-1,0 \mu \mathrm{m}$

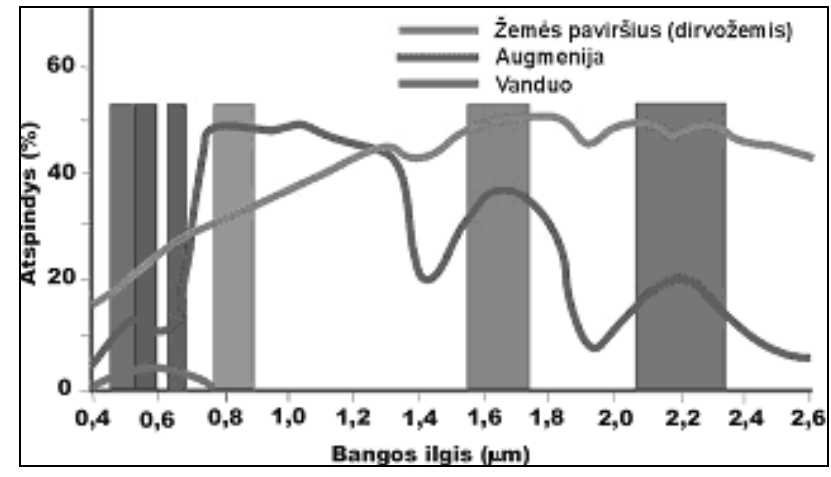

3 pav. Augmenijos, dirvožemio ir vandens tipiškas atspindys bei $T M, E T M+$ atspindžio registravimo juostų išsidèstymas

Fig 3. Vegetation, soil and water typical reflection and $T M$, ETM+ bands disposition ilgio infraraudonieji spinduliai. Apie 1,4 ir $2,0 \mu \mathrm{m}$ atspindžio sumažèjimai esti dẻl vandens sugerties augalo audiniuose. Žemès paviršiaus atspindys yra gana tolygus ir didejja ilgejjant bangos ilgiui. Kaip matome, raudonuju spindulių zonoje dirvožemio atspindys yra didesnis nei augmenijos, o infraraudonujų - mažesnis. Pagal ši skirtumą nustatomi vegetacijos indeksai $[5,6]$.

Palydovo LANDSAT 5 trečiosios juostos nuotrauka ir jos sklaidos histograma pateikta 4 pav. Histogramoje akivaizdi spalvinių reikšmių priklausomybè nuo atspindžio. Analizuodami antrosios juostos duomenis (4 pav.) matome, kad geriausiai atspindima žemès paviršius, o prasčiausiai vandens paviršius. Suskaidžius atspindi i 255 intervalus ir kiekvienam intervalui priskyrus skirtingą spalvą gaunamas matomas grafinis vaizdas. Histogramoje pateikiama kiekvieno atspindžio intervalų kiekis turimame vaizde.

\section{Tinkamiausio žemès paviršiaus skenavimo laikotarpio parinkimas kartografuojant žemès naudmenas}

Dabar žemès naudmenoms kartografuoti labiausiai tinka palydovu LANDSAT 5 ir LANDSAT 7 daugiaspektrès nuotraukos. Lietuvos teritorijos paviršiaus daugiaspektrių nuotraukų blokai, gauti iš palydovų, pateikti 5 pav. Kiekvienas palydovas virš mūsų teritorijos praskrenda tik 16 dienų periodais, taigi palydovai praskrenda virš Lietuvos teritorijos kas 8 dienos (lentelè).

Pastebime, kad pagal meteorologines sąlygas Lietuvos teritorija nèra tinkamiausia analizuoti distancinių tyrimų metodu, todèl tikimybė tam tikru metu gauti mums reikalingą kokybišką daugiaspektrę nuotrauką maža. Ši tikimybė padidètų, jeigu būtų galima naudoti keletą skirtingo laikmečio nuotraukų, gautų iš skirtingu palydovu. Norint parinkti tinkamą skenuoti laiką kartografuojant žemès ūkio naudmenas, reikia atsižvelgti $\mathfrak{i}$ augalų vegetacijos ypatumus ir sąsają su spektriniu atspindžiu.

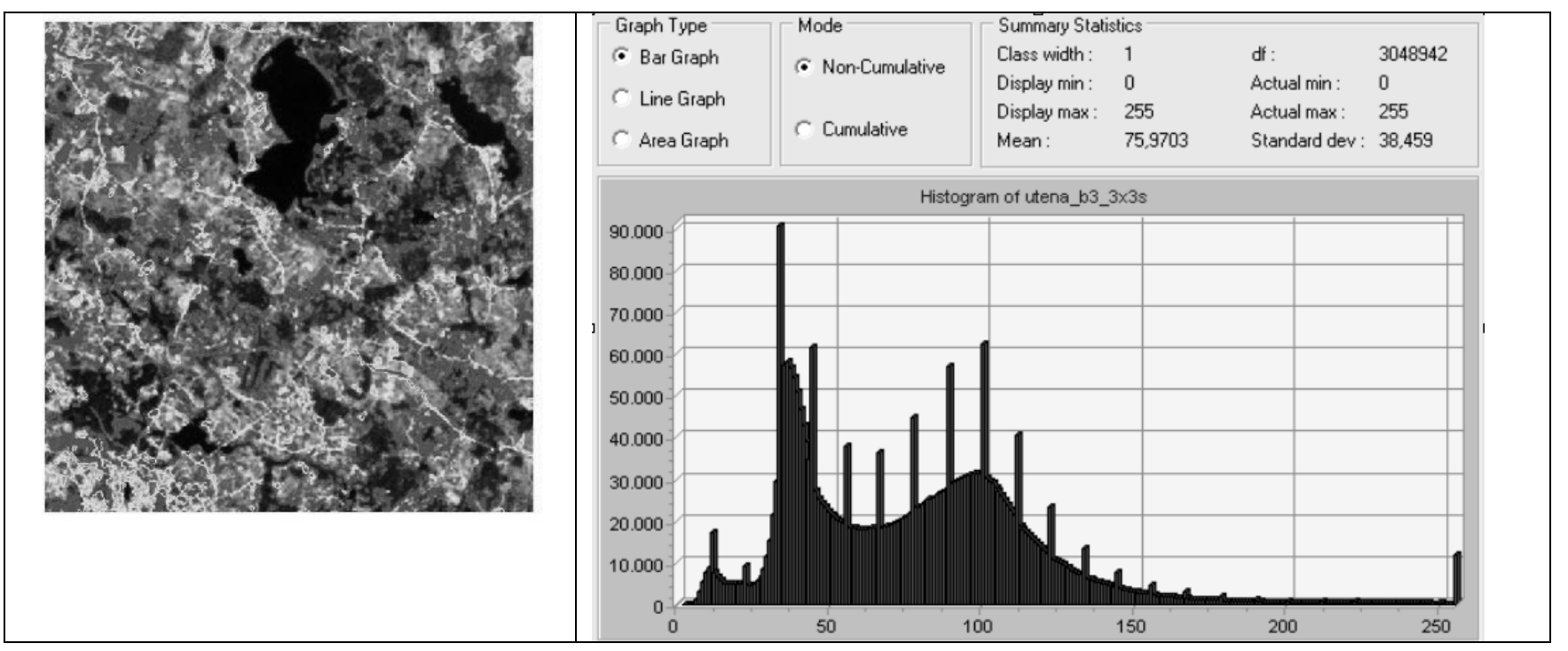

4 pav. Palydovo LANDSAT 5 trečiosios juostos nuotrauka ir jos sklaidos histograma

Fig 4. Three band picture of LANDSAT 5 and scattering histogram 

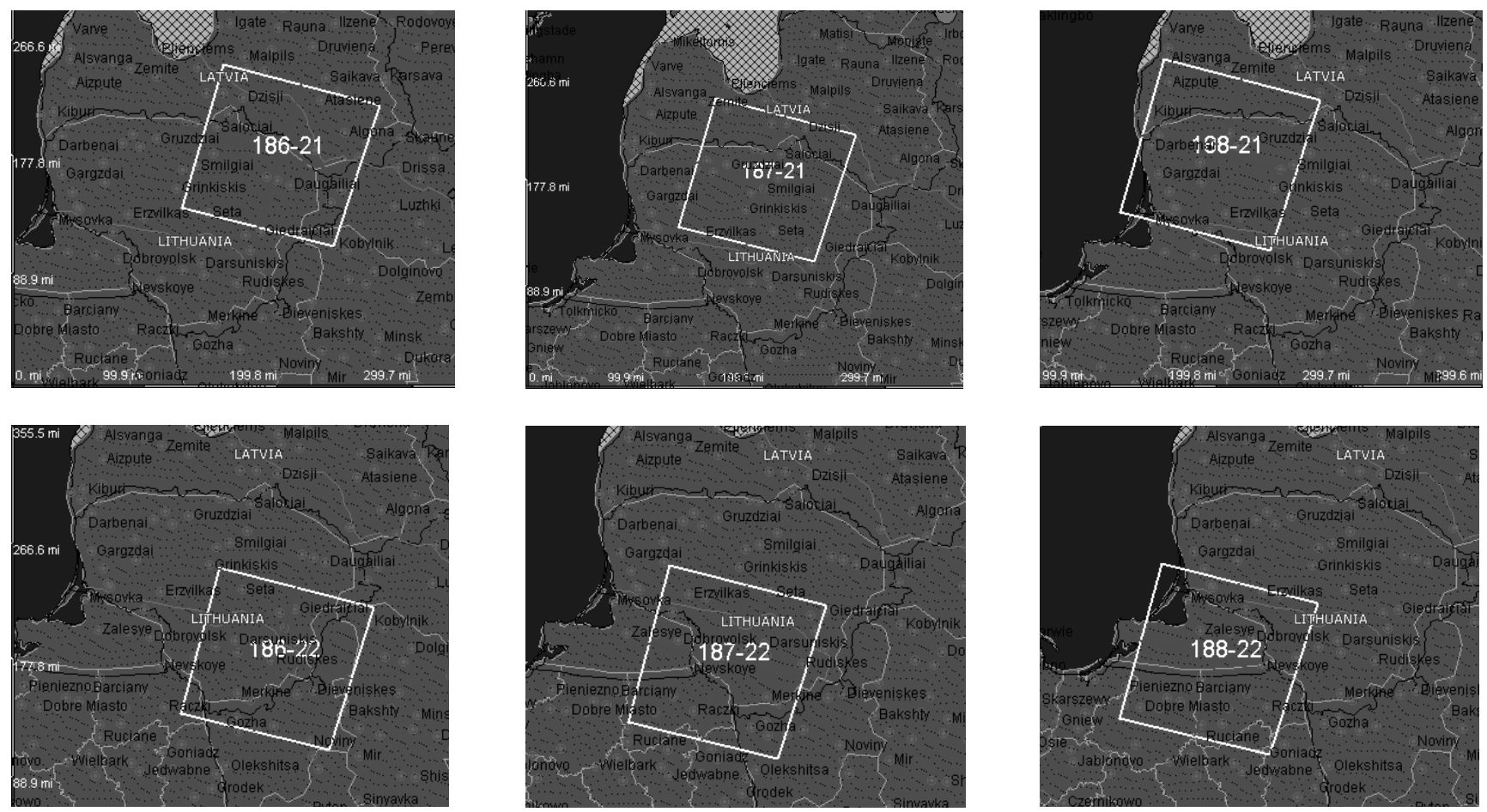

5 pav. Lietuvos teritorijos daugiaspektrių nuotraukų blokų numeriai

Fig 5. Numbers of multispectral image scenes for the territory of Lithuania

Tinkamo laiko parinkimas palydovinei nuotraukai gauti priklauso nuo siektinų tikslų. Kiekvienas augalas jo vegetacijos laikotarpiu atspindi infraraudonuosius spindulius skirtingai nuo kitų augalų. Tai priklauso nuo jų vegetacinès būklès. Miškų teritorijai kartografuoti palankiausias lapkričio - kovo mėnesių laikotarpis, nes spygliuočiu miškai žaliuoja ištisus metus. Dirbamos žemès plotams kartografuoti tinkamiausias laikotarpis, kai pievos, miškai dar turi žaliosios masès, o visų kitų žemès ūkio kultūrų derlius nuimtas, ir žemès danga likusi be augmenijos (spalis), arba ankstyvas pavasaris, kai sniego jau nebėa, o žieminių javų intensyvios vegetacijos periodas dar neprasidèjęs (balandis). Žiemkenčių plotams kartografuoti tinkamiausias būtų nevegetacinis laikotarpis bei spalio ir balandžio mènesiai. Šiuo laikotarpiu vyrauja daugiametès žalienos ir žiemkenčiai, tačiau skiriasi jų žaliosios masès kiekiai. Palydovinèje nuotraukoje sunkiausiai nustatomos daugiametès žalienos, nes jų vegetacijos laikotarpis ilgiausias - nuo balandžio iki spalio. Taip pat šiuo laikotarpiu žaliosios masès kiekis šioje žemès ūkio kultūroje yra pasiskirstęs nevienodai, nes laukai yra ganomi, šienaujami. Dèl sausros ar drègmès pertekliaus žalienos spektrinis atspindys skiriasi netgi tame pačiame lauke. Todèl tinkamiausias jų kartografavimo laikotarpis yra pirmoji pavasario pusè, nes žaliosios masès kiekiu žalienos skiriasi nuo žiemkenčių ir miškų.

Kartografuojant žemès naudmenas tikslingiausia rinktis skirtingu laikotarpių palydovines nuotraukas ir jose identifikuoti skirtingas žemès naudmenas. Taip išvengiama jas supainioti tarpusavyje ir gaunami tikslesni rezultatai. Tačiau tai reikalauja didelių laiko sąnaudų. Apibendrintieji tinkamiausio laikotarpio nustatymo rezultatai pateikti lenteleje. Antroje jos dalyje pateikta palydovu LANDSAT 5 ir LANDSAT 7 skridimo grafikai vegetacijos laikotarpiu 2005 metais.

Trys palydovu skridimo trajektorijos (186-188) eina Lietuvos teritorija. Iš kiekvienos trajektorijos reikalingos dviejų Lietuvos teritorijos blokų daugiaspektrès nuotraukos. Kiekviena nuotrauka turi unikalu numeri (pvz., 187-22, 5 pav.).

Analizuodami lenteleje pateiktus duomenis, galime nustatyti, kad, pvz., žalienoms kartografuoti vidurio Lietuvoje (187-21 ir 187-22 blokai) geriausiai tinka balandis ir pirmosios dvi gegužès dekados. Tam tinkamiausios LANDSAT 5 palydovo daugiaspektrès nuotraukos, darytos balandžio 4, 20 ir gegužès 6 dienomis, bei LANDSAT 7 palydovo daugiaspektrès nuotraukos, darytos balandžio 12, 28 ir gegužès 14 dienomis. Dirbamai žemei kartografuoti tinkamiausias balandis ir pirmoji gegužès dekada bei rugsèjo trečioji dekada ir spalis. Vakarinès Lietuvos dalies (188-21 ir 188-22 blokai) tinkamiausios yra LANDSAT 5 palydovo daugiaspektrès nuotraukos, darytos balandžio 11, 27 ir spalio 4, 20 dienomis, bei LANDSAT 7 palydovo daugiaspektrès nuotraukos, darytos balandžio 3, 19, gegužès 5, rugsèjo 26 ir spalio 12, 28 dienomis.

Kukurūzų laukams kartografuoti Rytų Lietuvoje (186-21 ir 186-22 blokai) tinkamiausia rugpjūčio antroji ir trečioji dekados bei rugsèjo pirmoji ir antroji dekados. Tam tinkamiausios yra LANDSAT 5 palydovo daugiaspektrès nuotraukos, darytos rugpjūčio 19 ir rugsèjo 4, 20 dienomis, bei LANDSAT 7 palydovo daugiaspektrès nuotraukos, darytos rugpjūčio 11, 27 ir rugsèjo 12 dienomis. 
Tinkamiausias laikotarpis tirti žemės naudmenas nuotolinių tyrimų metodu ir palydovų skridimo grafikai (13 - palydovo skridimo diena virš Lietuvos teritorijos)

The best time to identify land-tenures by remote sensing and satellite calendar (13 - day of satellite navigation over the territory of Lithuania)

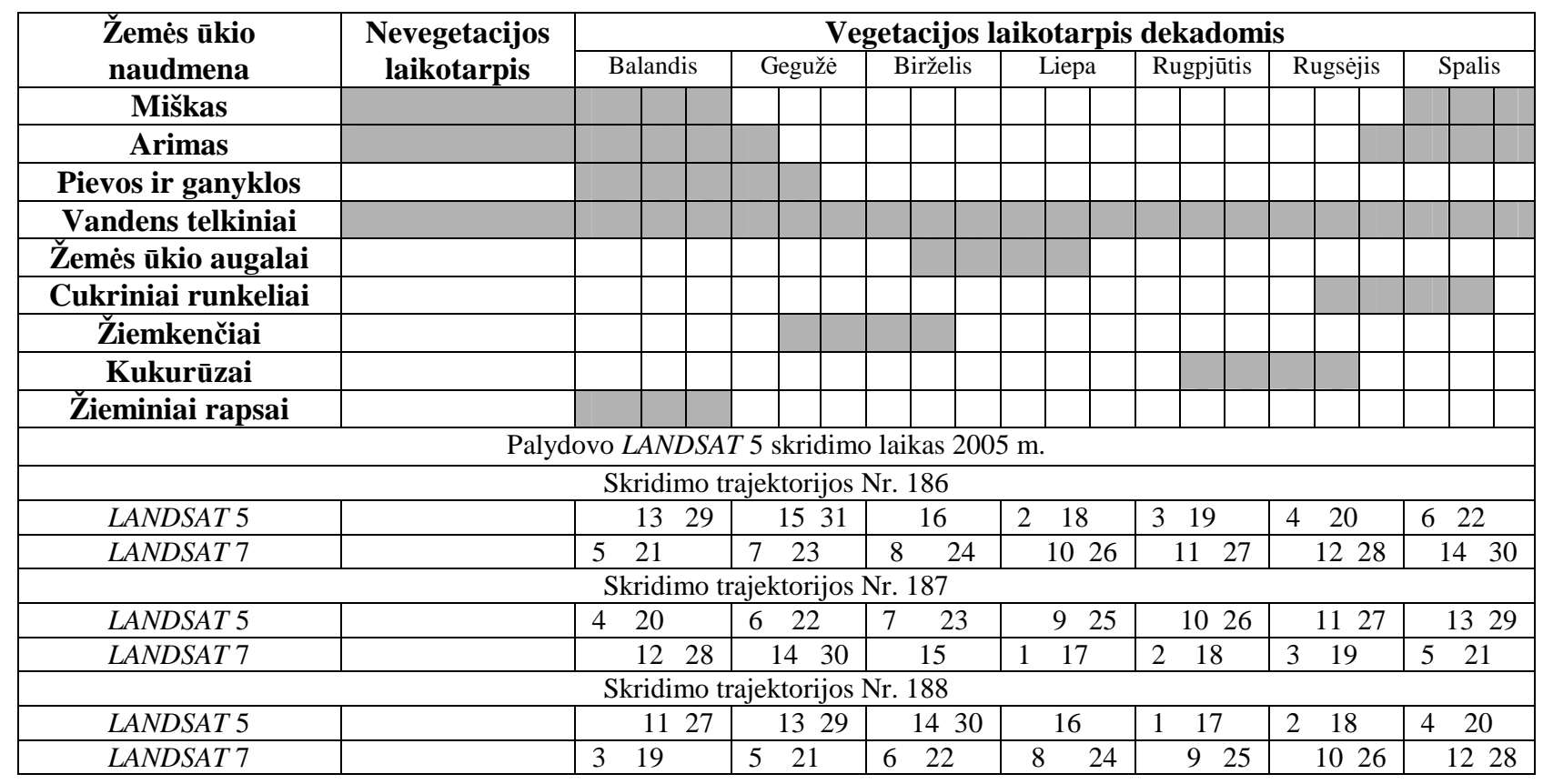

\section{Išvados}

1. Išanalizuotos augalinès dangos kartografavimo galimybès, taikant LANDSAT palydovų daugiaspektres nuotraukas. Parengtas žemès naudmenų kartografavimo nuotolinių tyrimų metodu tinkamiausių laikotarpių grafikas.

2. Nustatyta, kad taikant dviejų palydovu nuotraukas žemès paviršiaus skenavimo dažnis padidèja iki 8 dienų periodo. Tai leidžia tikètis gauti kokybiškus duomenis žemènaudoms kartografuoti tinkamiausiu laikotarpiu.

3. Daroma išvada, kad nuotolinių tyrimų duomenys tinka ne tik žemès naudmenoms kartografuoti, bet ir kultūrų brandai stebėti, nes augalams bręstant keičiasi ir vegetacijos etapas, todèl keičiasi atspindžio nuo žemès paviršiaus spektras.

4. Nustatyta, kad daugumos žemès naudmenu vegetacijos laikotarpis, Kuriuo galima jas kartografuoti taikant palydovines daugiaspektres nuotraukas, yra per trumpas.

5. Nustatyta, kad, palyginti su kitais augalais, kartografuoti žemès ūkio augalus yra kebliausia, nes Rytu ir Vakaru Lietuvoje galima gauti tik po dvi nuotraukas, tinkamiausias jiems identifikuoti.

6. Sunkiausia kartografuoti daugiametes žalienas, nes jų žaliosios masès kiekis yra netolygus.

7. Nuotoliniu tyrimu metodo kartografuojant žemès naudmenas rezultatų tikslumui ir patikimumui padidinti reikia rinktis ir kitų palydovų nuotraukas.

\section{Literatūra}

1. Kutra, S.; Berankienè, L. Tinkamiausias laikotarpis žemėnaudai nustatyti distancinių tyrimų metodu. Lietuvos žemés $\bar{u} k i o$ universiteto ir Lietuvos vandens ūkio instituto mokslo darbai, Nr. 17(39), 2001, p. 89-98.

2. Kutra, S.; Berankienè, L. Nustatyti distanciniu tyrimu metodo panaudojimo galimybes žemėnaudai vertinti vandens kokybès tyrimuose. Mokslo tiriamojo darbo ataskaita. Lietuvos vandens ūkio institutas, 2000, p. 1240.

3. Clark, R. N. Spectroscopy of Rocks and Minerals, and Principles of Spectroscopy. In: Manual of Remote Sensing, Vol 3, Remote Sensing for the Earth Sciences, (A. N. Rencz, ed.) John Wiley and Sons, New York, 1999, p. 3-58.

4. <http://www.eurimage.com/products/landsat.html> (žiūrèta 2005-11-28).

5. <http://speclab.cr.usgs.gov> (žiūrèta 2005-11-10).

6. Food and agriculture organization of the United Nations. Remote sensing applications to land resource. Remote sensing centre, 1990, p. 87-90.

Arūnas Bujauskas. Postgraduate student. Vilnius Gediminas Technical University. Dept of Geodesy and Cadastre $(\mathrm{Ph}+3705274$ 4703, Fax +370 5274 4705).

BSc (2004). Participated in national conferences.

Research interests: geoinformation systems, remote sensing.

Eimuntas Paršeliūnas. Associate Professor, Doctor. Vilnius Gediminas Technical University. Dept of Geodesy and Cadastre $(\mathrm{Ph}+3705274$ 4703, Fax +370 5274 4705).

Doctor (1992). Author of two teaching books and more than 40 scientific papers. Participated in many intern conferences.

Research interests: graphs theory in geodesy, treatment of geodetic networks, geoinformation systems. 